\title{
Are Modal Auxiliaries in Malaysian English Language Textbooks in Line with Their Usage in Real Language?
}

\author{
Laleh Khojasteh (Corresponding author) \\ Department of Foreign Languages, Shiraz Branch, Islamic Azad University, Shiraz, Iran \\ Tel: 60-123-804-248_E-mail: khojastehlaleh@yahoo.com \\ Reza Kafipour \\ Department of Foreign Languages, Shiraz Branch, Islamic Azad University, Shiraz, Iran \\ Tel: 98-917-315-8394Ｅ-mail: rezakafipour@gmail.com
}

Received: October 18, 2011

Accepted: December 2, 2011

Published: February 1, 2012

doi:10.5539/elt.v5n2p68

URL: http://dx.doi.org/10.5539/elt.v5n2p68

\begin{abstract}
Based on the discrepancies found in many Malaysian English language textbooks, a detailed analysis on the way modal auxiliary verb forms and their semantic functions were introduced and presented in texts and exercises in five Malaysian textbooks was done. For that to be achieved, a qualitative page-by-page content analysis was applied. From the discussion of the grammatical progression in the textbooks, we can see that the presentation of modal auxiliaries in Malaysian English language textbooks is not fully in accordance with their use in natural English. Besides that, although recycling modal auxiliaries throughout different levels in order for the students to fully grasp their various meanings is advised by many linguists, we could see that Malaysian textbook authors used only a few of the same modals to express repetitive semantic functions. Accordingly, changes are recommended in order to bring the English taught in textbooks into accordance with real-life language use.
\end{abstract}

Keywords: Modal auxiliaries, Corpus linguistics, Textbooks, Real language use, Grammar teaching

\section{Introduction}

Regarding the presentation of modal auxiliary verbs in textbooks, so far it has been reported that textbooks which were not written based on empirical studies fail to teach modal auxiliary verbs on three accounts: (i) textbook writers misinform learners as to the range of modal language available to them; (ii) learners are given inaccurate descriptions of both the qualitative functions of modality and the frequencies with which the modals occur; and (iii) modal language is often stigmatized and is said to be unnecessary when in fact corpus studies show it to be a principal feature of communication (Holmes, 1988; Hyland, 1994; McEnery \& Kifle, 2002).

Refer to that, although most grammarians and linguists have listed nine central modals, Kurikulum Bersepadu Sekolah Menengah (KBSM) syllabus in Malaysia lists only six central modals and one semi-modal for Malaysian secondary school textbooks. The modals shall and would are not featured in the primary and secondary school textbooks. In addition, the modal could, which has been introduced to students at primary level, is not reintroduced to them in secondary school textbooks. As De Silva (1981, P.12) asserts "modal auxiliary system used in the Malaysian schools has been altered and functionally reduced through the continued use of fewer and semantically salient modals that serve multi functionally across notions". The limited exposure of Malaysian learners to different forms of modal verbs has resulted to an overuse of one form or function over the others which have been reported in many studies conducted on Malaysian learner corpora to date (Manaf, 2009; Rosli \& Edwin, 1989; Wong, 1983).

Although the lack of equal counterparts between the English modal system and that in Bahasa Melayu (official language of Malaysia) might be the reason for this confusion for Malay learners, Romer (2005) believes that this problem is owing to the teaching materials. In this study, hence, all grammar sections and relevant exercises that deal with modal auxiliary verbs were examined to see the grammatical progression and the kind of explicit information that the textbook authors provided in Form 1 through Form 5 on the use of modal auxiliary verbs in English. The leading question was:

"How the modal auxiliary verbs introduced and presented in texts and exercises throughout Form 1 to Form 5 Malaysian English language textbooks?" 


\section{Approaches to Grammar Teaching}

To date teaching grammar has continued to occupy a central place in language pedagogy, and publications on how to teach linguistics forms, especially grammar, consist of accounts of various pedagogical options available to teachers and their relative advantages. Proposing a multifaceted teaching approach, Celce-Murcia and Larsen-Freeman (1999) firmly believe that it doesn't really matter how to raise learners' consciousness toward distinctive features of particular grammatical form, as what really matters is to find a way to help learners master both the structure of the target language and its communicative use. Celce-Murcia and Hilles $(1988$, p. 466) also propose that "grammar should never be taught as an end in itself, but always with reference to meaning, social factors, or discourse or a combination of these factors". To achieve this, Celce-Murcia and Larsen-Freeman (1999) argued for using different teaching techniques for teaching a three interrelated dimensional grammar framework that consists of form (morphology and syntax), semantics (meaning) and pragmatics (use). To elaborate on this, in terms of teaching modal auxiliary verbs, when dealing with forms, it is important to inform learners how modals are constructed (e.g., lack of tense, lack of subject-verb agreement), with regards to meaning how polysemous they are (e.g., can means "ability", possibility and permission) and for pragmatics how various social functions are performed when making requests or giving advice. According to Celce-Murcia and Larsen-Freeman (1999), the combination of the above mentioned dimensions helps learners to learn to use grammar "accurately, meaningfully and appropriately" (p. 5).

To create a multi-layered syllabus, however, Thornbury (2004) suggested a "functional syllabus ... [that is] organized around the communicative purposes for which language is used" (p. 10). Inherent in this view point on language, then, is the idea that what actually real language users 'say' is more important than what people think it 'should' be used (descriptivism/prescriptivism dichotomy) (Thornbury, 2004, p. 11). This functional or pragmatic approach, according to Mitchell and Myles (2004), "[is] concerned with the ways in which second language learners set about making meaning, and achieving their personal communicative goals" (p. 131). For that to be achieved, additional principles such as tasks, topics and genres should be included in such multi-layered syllabi (Thornbury, 2004).

With the revival of grammar in the context of performing a communicative task, two influential theoretical concepts, namely focus-on-form and consciousness-raising, emerged. In contrast to traditional instruction of focus-on-forms in which the primary focus of attention was merely on the form of the target language, in focus-on-form this attention was moved toward meaning. Similarly, consciousness-raising is a tool to equip a learner with "a declarative rather than procedural knowledge" of a particular grammatical structure (Ellis, 2002, p. 168). Although Krashen (1982) argued that acquisition is largely an unconscious process, many theorists including Ellis (2002) believe that drawing learners' attention is a conscious process which eventually leads to acquisition. The famous example repeatedly mentioned in the reviewed literature is the case of; Richard Schmidt, who was able to notice certain Portuguese grammatical features when he interacted with Brazilians only because his attention was formerly drawn to the same grammatical features in his formal language classes (Schmidt, 1990). After this experience, Schmidt (1990) concluded that noticing is a prerequisite for acquisition. However, Thornbury (2004) argues that although attention is a prerequisite for learning, without understanding, attention is probably a waste of time. He further argues that the efficiency of presenting any grammatical feature to learners mainly depends on the degree of attention it arouses; hence, "the amount and the quality of contextual information, explanation and checking" plays an important role in arousing the attention (Thornbury, 2004, p. 26). One way this can be achieved in textbooks, for instance, is to make sure that a particular word is repeated and recycled adequately to ensure acquisition. "It has been estimated that, when reading, words stand a good chance of being remembered if they have been met at least seven times" (Thornbury, 2002, p. 24).

From the teaching point of view, there is more to knowing a language than knowing its grammar (Thornbury, 2004) and for sure it is not possible to teach everything about English to ESL/EFL students (Celce-Murcia \& Larsen-Freeman, 1999). Hence, it is important to emphasize equally, rules of forms as well as rules of meanings (pedagogic rules) to equip learners with the means and confidence to generate language with a reasonable chance of success (Thornburry, 2004).

\section{Methodology}

Based on the discrepancies found in many textbooks regarding the presentation and progression of grammatical structures, a detailed analysis on the way modal auxiliary verb forms and their semantic functions were introduced and presented to Malaysian students in the Forms of 1 to 5 Malaysian English textbooks was done for this question. For that to be achieved, a qualitative page-by-page content analysis was applied to analyze the ways in which modal auxiliary verbs are presented in the textbooks. In this regard, each and every page included a lesson in modal auxiliary verb was photocopied and analyzed thoroughly to first investigate the ways in which modals are 
introduced and presented to students (e.g. in grammar boxes) throughout the textbooks of Form 1-5. Next, a detailed analysis carried out to find out whether the featured semantic functions of the assigned modal auxiliary verbs in these textbooks are in line with the ones in real language. Finally, the ways in which modals are presented in the exercises were studied to see whether Malaysian students are exposed to enough communicative tasks regarding modal auxiliary verbs.

\section{Results}

\subsection{Form 1 Textbook}

The first two modals introduced explicitly to lower secondary Malaysian students are the modals should and must to present the semantic function of "giving advice". The grammar box is then backed up with three tasks that are summarized in Table 1.

Next taught is the modal will which is paired with going to expressing future plans or intentions. For this semantic function two sets of exercises were applied. Will reintroduced to students at this level with two other functions. First the 'request' sense of will is introduced in one sample sentence and then the 'volition' sense of will is exemplified in another sentence. The exercise "fill in the blanks" is followed by six interrogatives that allow students practice the 'request' sense of will. Next task provides students with a situation that allow students make a request using will. The 'volition' sense of will is then exercised in the jumbled words exercise asking students to rearrange the words in the sentences.

\subsection{Form 2 Textbook}

This Form starts with introducing can to express both 'ability' and 'possibility' plus its negative counterpart, cannot; 'inability' and 'impossibility'. For each function one example sentence is provided.

The first task includes four pictures illustrating actions that can or cannot be done by the figures in the cartoons. Next to speech bubbles missing the modal verbs can or cannot that needs to be filled by students. However, the second task gives more freedom to students to come up with their own sentences. All this, is summarized in Table 2.

Then, must and its negation counterpart mustn't is introduced to students to emphasize on the "necessity" meaning.

In chapter 15 of Form 2 textbook, may and might are introduced to students. At first (epistemic) possibility meaning of both modals are presented and then one sample sentence is followed by the instruction which shows that may and might can be used interchangeably in a given situation. Then, may is reintroduced by another meaning that is the (deontic) permission sense.

\subsection{Form 3 Textbook}

Chapter 6 of Form 3 textbook gives a revision of may and might. As regard to the semantic functions of may and might, we get to know that both are used to express 'possibility' meaning, however, this time we also find a brief information on the lower degree of 'possibility' in terms of might as opposed to may. Students then were asked to add more suggestions using may or might. The summery of the modals introduced and the included tasks can be seen in Table 3.

The next pair introduced to students arecan and mustfor semantic functions of 'ability' and 'necessity' respectively. The first grammar exercise dedicated to fill in the blanks using can, cannot, must or must not in six sentences. This is followed by another task asking students to come up with sentences on how they can stay healthy using can, cannot, must and must not. Also discussed in the grammar section in chapter 15 is the modal will. Then, students were asked to complete the extract from a letter with simple future tense form of the words in the brackets.

\subsection{Form 4 Textbook}

In Form 4, should, and need (and need to) are paired together as modals but taught separately in two different grammar boxes.

In the first grammar task, students invited to look at the cartoons provided and read the sentences beside the cartoon, make a sentence using should or should not for each illustration. Then students are asked to fill the slots in the dialogue by should, should not, need and need not. In the extract provided to students, they should use should or should not if the brackets besides the word missing indicate 'advice' and they should use need or need not if the brackets indicate 'necessity'. The introduced modals plus the included tasks are summarized in Table 4.

\subsection{Form 5 Textbook}

Chapter 7 of Form 5 textbook gives a revision of the 'possibility' sense of may and might. As for the first task, students were asked to read a question posed by a counselor and suggest what may or might be wrong with a boy who has been quiet lately. Then, will is mentioned expressing future tense. Will in this section paired with going to 
and 'present continues' to talk about future. This grammar box then is backed up with a task that requires students to fill in the slots in four sentences using will. Will, going to and present continuous tense were first practiced separately in separate exercise sets. However, at the end, there is one fill in the slot exercise that invited students to fill in the gaps with either will, going to or present continues. The summary of the tasks can be seen in Table 5 .

\section{Summary and Discussion}

Concerning the organization of modal auxiliary verb forms and their semantic functions, it is not really clear 1) why textbook writers have started their introduction with this order should $\rightarrow$ must $\rightarrow$ will $\rightarrow$ can $\rightarrow$ may $\rightarrow$ might, 2) what was their rational in pairing and not pairing certain modals the way they did in different forms (e.g. pairing 'ability' can with 'necessity' must in Form 3 textbook) and finally 3) why they emphasized only on certain semantic functions ignoring the rest. From language teaching point of view, Hullen (as cited in Celce-Murcia and Larsen-Freeman, 1999) believes in didactic grammar that is "problem-oriented, semantically based and relevant for language use" (p. 14). This grammar, according to Mindt (as cited in Romer, 2004b) should solve the relevant textbook problems of "selection", "progression" and "presentation" by frequency data from corpus evidence. Although Howarth (1998) and Widdowson (1990) questioned the pedagogical usefulness of frequency lists generated by corpora because they believe frequency does not indicate any significance, especially in the area of problematic processing of language, Romer (2004a) claims that frequencies are the keys to lead us to words or structures which are central in a language. Without them, she notes, it is difficult to decide what should be included in teaching materials and specifically in the case of modal auxiliary verbs, which modals for example should be prioritized over others in EFL/ESL teaching (Romer, 2004a).

Apart from 'selection' and 'progression' problems discussed above, if we divide the possible 'presentation' issues existed in textbooks into structural and semantic/ pragmatic types, for sure the most obvious relevant issue in terms of modal auxiliary verb forms is lack of enough information on syntactic properties of modal auxiliary verbs in Form 1 to 5 Malaysian English language textbooks. For instance students are not explicitly presented with modals' lack of subject-verb agreement or their lack of tense while according to Celce-Murcia and Larsen-Freeman (1999), Romer, (2004a) and Decapua (2008) this morphological defectiveness proved to be as an insurmountable barrier particularly for lower level students. Although there has been a perennial area of debate about explicit over implicit grammar instruction (e.g. Ellis, 1992, Krashen, 1982 and Prabhu, 1987), Ellis (2002, p. 169) believes, the grammar should be consciousness-raising in that provide the opportunity for learners to 'know about it'. Conscious-raising does not necessarily involve the learner with production, but through explicit knowledge of grammar, "students have a clear idea about what the targeted structure consists of" (Ellis, 2002, p. 169). Respectively, in the analysis Manaf (2007) did on Malaysian learner corpus (EMAS), she reported that students showed numerous syntactically inaccurate modal structures in their essays. As she reported, one of the difficulties Malaysian students had in their writings was inflecting the main verb that directly preceding the modal auxiliary (Manaf, 2007). Sample examples retrieved from Manaf (2007, p. 174) analysis can be seen here:

(1) She can $^{\prime} *$ swam. (Form 1 student)

(2) That the moment they can $^{2} t^{*}$ forgot from their mind. (Form 1 student)

(3) After a few days, Hana can* came out from the hospital. (Form 1 student)

(4) I like to go there ... and I can* joking with my family. (Form 1 student)

As for the latter issue, semantic/pragmatic type, there can be seen a noticeable imbalance between the use of certain modal verbs or specific modal meanings in the textbooks and their actual occurrence in a real language use. Although KBSM stipulated only six modal auxiliary verb forms, but we can clearly see that these modals have been repetitively used to express similar meanings over and over again resulted for the textbooks to provide a rather monolithic view of what modal auxiliary verbs can express. In this simplified picture, overemphasise of one function over the others, unfortunately was at the expense of other important functions that students equally needed to be exposed to. For example may and might has been constantly taught (Form 2, Form 3 and Form 5) to express 'possibility', whereas 'permission' meaning has been marginalised with an exception of 'permission' may with its superficial introduction in Form 2. This might be understandable for might which its permission meaning is rather rare, but in terms of may, its 'permission' meaning is the second important meaning of all modal auxiliary verbs used for permission (Romer, 2004a). This also is the case for can that its 'ability' and 'possibility' meanings overemphasized while nothing has been mentioned about its 'permission' meaning that of all modals used to express 'permission', this sense ranked first based on current corpus-based research (Biber, Johansson, Leech, Conrad, \& Finegan, 1999; Decapua, 2008; Romer, 2004a).

Lack of enough context for teaching modal auxiliary verbs, did not take into account the relevant features of social 
interaction in case of many modal auxiliaries. The most obvious case is may and its 'permission' meaning for example in Form 3 textbook. According to Celce-Murcia and Larsen-Freeman (1999) when teaching modal auxiliaries such as may in "you may leave the room", the relevant features of social situation should be clear for students that first this situation is formal and second this social situation gives the authority to the speaker to grant a permission to the interlocutor. The students should be clear that if this is not the case the situation can be informal and they can use can instead of may (Celce-Murcia \& Larsen-Freeman, 1999). In terms of may and introduction of specific requests for permission in Form 2 textbook by not providing enough context for a sentence "May I come in?" it is not really clear what kind of social situation the sentence is depicting and of course using only one sample sentence and lack of even one exercise to practice the 'permission' meaning of may shows how authors of the textbook neglect the important pragmatic features of this modal. Perhaps if may was paired with can, it would be easier for students to see how context might influence their choice of using either may or can in different situations (Portner, 2009). If this was the case students could also see the difference between the subject pronouns (I and we) that only collocate with may and the freedom of their choice in collocating any subject pronoun with can when it comes to 'permission' sense (Decapua, 2008). Finally, textbooks totally lack one major system in the social use of modals to respond to permission. Although, may, can, could and might can be used to ask for permission, only present tense forms of these four modals can be used in granting the permission such as "yes, you may/ no, you may not and yes, you can/ no, you can 't' (Celce-Murcia \& Larsen-Freeman, 1999).

Very much marginalized in the textbooks is the making request of a general nature with modal auxiliaries of will, would, can and could. Among the above mentioned modals, will has been introduced to students of Form 1 to express 'request', however, the authors have totally ignored the role of pragmatics in formal and informal situations. Although, will is one of the modals that can be used to make request, but in formal contexts its past counterpart, would, is preferred. According to Celce-Murcia and Larsen-Freeman (1999, p. 145) not knowing the pragmatic functions of these modals in making request is the main reason ESL/EFL students usually perceived "aggressive and abrupt" by native speakers because they do not know how to soften their request by using would and could instead of will and can in face-to-face conversation. Supported by Decapua (2008), ESL/EFL learners overuse can and will instead of could and would since they are unaware of interactional functions of softening statements. Portner (2009) believes pragmatics plays an essential role when dealing with modality and Kratzer (1981) believes in giving more weight to the pragmatics rather than distinguishing one sense of a modal from another in textbooks. However, what we can clearly see in Form 1 textbook is that the information for students is thus misleading; some implicitly, by not covering enough conversational background and some explicitly, by suggesting that will is used in formal situations such as a shoe shop, a restaurant and home (making request from parents vs. sisters or brothers). By wiping out could and would from textbooks, of course the authors did miss the chance to introduce students to another obvious difference between using can/could versus will/would when making request. According to Celce-Murcia and Larsen-Freeman (1999, p. 145) can/could is used to make a request when the speaker question the possibility of responding to a request as in "could I talk to you for a minute?" while in terms of will and would the speaker seems to "query the willingness of the addressee" as in "would you open the door?".

Turn to the modals with their possibility meanings, we can say that this meaning has been presented by can and may and might. Among the four modals that express possibility, of course, could has been missing but even the rest has not been presented to learners appropriately. 'Possibility' can has been presented only once in Form 2 while 'possibility' may and might has been introduced and reviewed three times in Form 2, Form 3, and Form 5 textbooks. As for may and might, this meaning is introduced to Form 2 students while nothing has been mentioned about their degree of certainty. It is in Form 3 that students are told that might is a little sure than may, however, in other Forms may and might was used interchangeably in all the exercises provided. The problem here is that 'possibility' can, may and might are introduced to learners in various chapters and different textbooks. Introducing possibility and logical probability meanings like this, according to Celce-Murcia and Larsen-Freeman (1999) do not help students to see the upward trend in the degree of certainty regarding the reference. These meanings range from slight "possibility" (may, might, could) to a high degree of "certainty" (must). This is called Kratzer's (1981) ordering semantics for modals that clarify the distinction somewhat more concretely. This, according to Portner (2009, p. 71) can create a simple and less complex situation for specially "first-time students" to understand modality. Graded and comparative modality has also been supported by Portner (1998) and Von Fintel (1999) for its practical reasons. Speakers use these modals to indicate their level of certainty about something. A good way to help learners visualize the difference in probability and possibility reflected by these modals is to use a scale (Decapua, 2008).

Concerning the function of modal auxiliary verbs, the information given for most modals in textbooks, is rather general. In fact this kind of rules might add to the complexity of the students' understanding rather than simplifying their comprehension. For example, when should and must are introduced to students in Form 1 textbook, they are 
introduced and presented based on the emphasis the speaker wants to give to each proposition. Although, based on Swan's (as cited in Thornbury, 2004) characteristics of good rule, the applied rule in Form 1 textbook is simple, it also lack the "limitation criteria" in which shows the learner what the limits are.

Finally, after dealing with presentation and explanation stages, the practice stage in textbook exercises is discussed in the following. As it can be clearly seen from Tables 1 to 5 the number of practice exercises shrinks toward the upper level textbooks (e.g. Forms 4 and 5). This is a pertinent point to be noted, rationalizing that tapering off in practice and pragmatic recall, review, and application of what has been learned in earlier years will impact negatively on the eventual learning and acquisition of the previously taught grammatical points at various levels. Tables 1 to 5 provides an overview and clearly shows how in Forms 4 and 5, such easing off of exercise activities has occurred.

In many cases exercises are information- or opinion gap exercises that are based on the production of entertaining ideas which according to Ur (2006) are the most productive and interesting type of exercises. For example, in Form 5 textbook, a situation has been presented to students (a quiet boy) and students were asked to brainstorm their comments in order to suggest possible reasons with modals to be used (may and might) dictated to them in advance. However, there are as well practice exercises that are controlled or contextualized with less emphasis on communicative tasks. For example, we can see in Figure 1 (Form 1) that the applied mechanical drill does not provide any opportunity for students to practice grammar in oral and written interactions because the form, meaning and use are separated and students can easily supply the correct grammatical form without really needing to understand or communicate anything. Although this might be acceptable for lower level students, these controlled exercises can still be seen in Form 3, 4 and 5 repetitively. In Form 3, for example, the exercise (Figure 2) is based on mere technical manipulation and students are required to fill in all the slots with the modal will and main verb provided to students in the parentheses. In Form 5 (Figure 3) students are intentionally told what modal auxiliary verb they have to choose to fill in the blanks. Practicing a grammatical structure under controlled conditions like the above mentioned exercises, according to Ellis (2002), "does not seem to enable the learner to use the structure freely" (p. 170). In addition to that, in some cases the featured modal was not practiced at all. For example, in terms of may and its 'permission' meaning in Form 2, although students are provided with explicit grammar instruction, they are not required to practice it. Ur (2006) believes, when dealing with specific grammatical structures, students should be exposed to not only mechanical repetition of forms, but also "repeated reception and production" as well as register-specific descriptions (p. 12). Furthermore, regarding the communicative type of exercises emphasized by Ur (2006), none of the assigned modal auxiliary exercises presented in the textbooks of Form 1 to 5 required students to role-playing, guessing, describing pictures, writing letters or alike that support successful communication across a variety of communication contexts. A communicative task, according to Nunan (1989) is a task which "involves learners in comprehending, manipulating, producing or interacting in the target language" (p. 10). Referring to Vygotsky's (1978) sociocultural theory, Smith, Butler, Griffith and Kritsonis (2007) believes that it is not only in the social interaction (a novice and a more knowledge person) that learning can occur, but also properly designed materials can greatly influence the learning.

\section{Conclusion}

From the discussion above, we can clearly see that the presentation of modal auxiliary verbs in Malaysian English language textbooks is not fully in accordance with their use in natural English, and that changes are strongly recommended in order to bring the English taught in textbooks fully into accordance with real-life language use. Frequency information on pragmatic functions did not taken into consideration by Malaysian textbook authors. For example, may and might which ranked 5th and 8th respectively in real language use have been overrepresented throughout the textbooks whereas can and its 'permission' meaning which ranked first among other 'permission' meanings never been taught explicitly throughout the textbooks. It is probably advisable to also draw Malaysian students' attention to other pragmatic functions such as responding to a request and granting permission that were not included in their textbooks for explicit attention. In consciousness research, De Bot, Lowie and Verspoor (2005) emphasized on the importance of noticing and indicate that "some level of attention is required" to uptake a new information. In this regard, they believe, "instruction may have an awareness-raising effect, increasing the likelihood of noticing features in input through the establishment of expectation and comprehending." (p. 8). Besides that, although Thompson (2002) insisted on repeating modal auxiliary verbs throughout different levels in order for the students to fully grasp their various meanings, we could see that Malaysian textbook authors used only a few of the same modals to express repetitive semantic functions. This, according to Manaf (2007) has directly affected Malaysian learners output since the same tendency could be seen in their essays.

\section{Suggestions for the Improvement of Teaching Materials}

This study tends to suggest that students are explicitly provided with enough information about rules and regulations 
in terms of modal auxiliary verbs in their textbooks because otherwise it is hardly surprising to see that they face difficulties in constructing the sentences. Furthermore, it is advisable to seek insight from corpus evidence as regards to the content and the sequencing of the curriculum and the weight that is given to different items in classroom activities. Kennedy (2002), among others, points to the need to concentrate initial teaching on high frequency items and to grade vocabulary and structures accordingly. Respectively, Conrad \& Biber (2005) emphasizes on the importance of the frequency information for teachers because it helps them to decide which items to emphasize, for example, to provide students practice with the items they are most likely to hear outside the classroom.

More emphasis should be put on the most common functions identified for modal auxiliary verbs. Even the proportions given to different senses of a polysemous modal verb in a textbook should respect that the same tendency exists in real-life situations (Romer, 2004a; 2005). For example, the "ability" and "possibility" senses of can are equally favoured in real language use; hence, the weight given to these senses should follow a similar scale in textbooks. Similarly, since 'permission' sense of can is ranked ahead of may, could and might, it deserves more attention in Malaysian teaching materials because a lack of it might give the wrong impression to Malaysian students that for instance, can is only used to express "ability" and "possibility". The same argument is applicable for other modal forms and their semantic functions. Although corpus-driven studies report a rare frequency of shall (see Biber et al., 2002), this should not necessarily mean that we should neglect it. According to Romer (2004a), the prediction meaning of shall is among one of the most important meanings $(31 \%)$ in BNC data evaluation of Spoken English. Furthermore, according to Conrad (2000), rare grammatical features can have important discourse functions, in particular, registers; hence, it is vital that decisions about pedagogy be based on corpus linguistics, by "taking into account functional descriptions and frequency information as well as analyses of students' needs" (p.51).

Finally, for clarifying the pragmatic functions of should and must for students in the textbook, the authors probably should not have used sample sentences that were applicable to both modals. This could have been done by indicating how serious the consequences are for not following the previous assigned rules (Bybee, Perkins \& Pagliuca, 1994). Accordingly, as for must we deal with serious consequences if we don't follow the rules while should follow wider set of rules which might have potential serious consequences or might be violated without anything terrible happens (Portner, 2009). According to Celce-Murcia and Larsen-Freeman (1999) other important factors that really differentiate between our choice of should and must are (1) the speaker's degree of authority and (2) the urgency of the advice.

\section{References}

Biber, D., Johansson, S., Leech, G., Conrad, S., \& Finegan, E. (1999). Longman Grammar of Spoken and written English. Harlow: Pearson Education.

Bybee, J. L., Perkins, R. D., \& Pagliuca, W. (1994). The evolution of grammar: tense, aspect, and modality in the languages of the world. Chicago: University of Chicago Press.

Celce-Murcia, M. (1991). Language teaching approaches: An Overview. New York: Newbury House.

Celce-Murcia, M., \& Hilles, S. (1988). Techniques and resources in teaching grammar. New York: Oxford University Press.

Celce-Murcia, M., \& Larsen-Freeman, D. (1999). The Grammar book: an ESL/EFL teacher's course. $2^{\text {nd }}$ ed. Boston: Heinle\&Heinle.

Conrad, S. M. (2000). Will corpus linguistics revolutionize grammar teaching in the 21st century? TESOL Quarterly 34(3), 548-60. http://dx.doi.org/10.2307/3587743

Conrad, S., \& Biber, D. (2005). The frequency and use of lexical bundles in conversation and academic prose. In W. Teubert, \& M. Mahlberg (Eds.), The corpus approach to lexicography. Lexicographica: International Annual for Lexicography. pp. 56-71

De Bot, K., Lowie, W., \& Verspoor, M. (2005). Second language acquisition: An advanced resource book. London: Routledge.

Decapua, A. (2008). Grammar for teachers: A Guide to American English for Native and Non-Native Speakers. New Rochelle: Springer.

De Silva, E. (1981). Forms and functions in Malaysian English: the case of modals. SARE.3, 11-23. McEnery, T., \& Kifle, N. A. (2002). Epistemic modality in argumentative essays of second-language writers. In J. Flowerdew (Ed.), Academic discourse. Harlow: Longman. pp. 182-195

Ellis, R. (1992). Grammar teaching - practice or consciousness raising? Clevedon: Multilingual Matters. 
Ellis, R. (2002). Grammar teaching - practice or consciousness raising? In J.C. Richards, \& W. A. Renandya (Eds.), Methodology in language teaching: An Anthology of Current Practice. Cambridge University Press, Cambridge. pp. 167-174. http://dx.doi.org/10.1017/CBO9780511667190.023

Holmes, J. (1988). Doubt and certainty in ESL textbooks.Applied. Linguistics, 9(1), 21-44. http://dx.doi.org/10.1093/applin/9.1.21

Howarth, P. (1998). Phraseology and second language proficiency. Applied linguistics. 19(1), 24-44. http://dx.doi.org/10.1093/applin/19.1.24

Hyland, K. (1994). Hedging in academic writing and EAP textbooks. English for Specific Purposes, 13(3), 239-56. http://dx.doi.org/10.1016/0889-4906(94)90004-3

Kennedy, G. (2002). Variation in the distribution of modal verbs in the British National Corpus. In R. Reppen, S. Fitzmaurica, \& D. Biber (Eds.), Using Corpora to Explore Linguistic Variation. Amsterdam: John Benjamins. pp. 73-90

Krashen, S. (1982). Principles and Practice in Second Language Acquisition. Oxford: Pergamon.

Kratzer, A. (1981). The notional category of modality. In H. Eikmeyer, \& H. Rieser (Eds.), Words, Worlds and Contexts. Berlin: Walter de Gruyter. pp. 38-74

McEnery, T., \& Kifle, N. A. (2002). Epistemic modality in argumentative essays of second-language writers. In J. Flowerdew (Ed.), Academic discourse. Harlow: Longman. pp. 182-195

Mitchell, R., \& Myles, F. (2004). Second language Learning Theories (2nd edition). London: Oxford University Press.

Nunan, D. (1989). Designing tasks for the communicative classroom. Cambridge: Cambridge University Press.

Portner, P. (2009). Modality. Oxford: Oxford University Press.

Prabhu, N. S. (1987). Second Language Pedagogy. Oxford University Press, Oxford.

Romer, U. (2004a). A corpus-driven approach to modal auxiliaries and their didactics.In J. Sinclair (Ed), How to Use Corpora in Language Teaching. Amsterdam: John Benjamins. pp. 185-199

Romer, U. (2004b).Comparing real and ideal language learner input: the use of an EFL textbook corpus in corpus linguistics and language teaching. In G. Aston, S, Bernardini, \& D, Stewart (Eds.), Corpora and Language Learners. Amsterdam: John Benjamins. pp. 151-168

Romer, U. (2005). Progressives, patterns, pedagogy. A Corpus-driven Approach to English Progressive Forms, Functions, Contexts and Didactics. Amsterdam: John Benjamins.

Rosli, T., \& Edwin, M. (1989). Error analysis of Form Four English compositions. The English Teacher, XVIII, $110-124$

Schmidt, R. (1990). The role of consciousness in second language learning.Applied Linguistics, 11(2), 129-158. http://dx.doi.org/10.1093/applin/11.2.129

Smith, C., Butler, N. L., Griffith, K.G., \& Kritsonis, W. A. (2007). The Role of Communication Context, Corpus-Based Grammar, and Scaffolded Interaction in ESL/EFL Instruction. The Lamar University Electronic Journal of Student Research, 4

Thompson, M. (2002). Modals in English language teaching. [Online] Available: http://www.telusplanet.net/linguisticsissues/modalsinteaching.html

Thornbury, S. (2004). How to teach grammar. Malaysia: Pearson Education Limited.

Ur, P. (2006). Grammar Practice Activities. Cambridge: Cambridge University Press.

Von Fintel, K. (2006). Modality and language. In D. M. Borchert (Ed.), Encyclopedia of philosophy (second edition). Detroit: MacMillan Reference USA.

Vygotsky, L. (1978). Mind in Society: The development of higher psychological Processes. Cambridge, MA: Harvard UP.

Widdowson, H. G. (1990). Aspects of language teaching. Oxford: Oxford University Press.

Wong, I. (1983). Simplification features in the structure of colloquial Malaysian English. Singapore: Singapore University. 
Table 1. Summary of modals taught, their semantic functions and practice tasks in Form 1 textbook

\begin{tabular}{|c|c|l|l|}
\hline Modals taught & $\begin{array}{c}\text { Semantic } \\
\text { functions }\end{array}$ & \multicolumn{1}{|c|}{ Exercises } & \\
\hline Must & Giving advice & Task 2: Rewrite (insert must) & $\begin{array}{l}\text { Task 1: } \\
\text { Discuss \& multiple } \\
\text { choice (should/must) }\end{array}$ \\
\hline \multirow{3}{*}{$\begin{array}{c}\text { Will (+ be } \\
\text { going to })\end{array}$} & Giving advice & Task 3: Rewrite (insert should) & \\
\cline { 2 - 3 } & Future plans & $\begin{array}{l}\text { Task 4: Matching } \\
\text { Task 5: Make new sentences(will or be going to can } \\
\text { be used interchangeably) }\end{array}$ \\
\cline { 2 - 3 } & volition & $\begin{array}{l}\text { Task 6: Slot-filling (choice of answers provided) } \\
\text { Task 7: Write sentences (make request) }\end{array}$ & \\
\hline
\end{tabular}

Table 2. Summary of modals taught, their semantic functions and practice tasks in Form 2 textbook

\begin{tabular}{|c|c|c|}
\hline Modals taught & $\begin{array}{l}\text { Semantic } \\
\text { functions }\end{array}$ & Exercises \\
\hline \multirow[t]{2}{*}{ Can } & ability & Task 1: Slot-filling (choice of answers not provided) \\
\hline & possibility & Task 2: Open-ended \\
\hline Must & necessity & $\begin{array}{l}\text { Task 3: Open-ended } \\
\text { Task 4: Rearrange words }\end{array}$ \\
\hline might & possibility & Task 5: Open-ended \\
\hline \multirow[t]{2}{*}{ May } & Possibility & $\begin{array}{l}\text { Task 6: matching (may/might can be used } \\
\text { interchangeably) }\end{array}$ \\
\hline & permission & - \\
\hline
\end{tabular}

Table 3. Summary of modals taught, their semantic functions and practice tasks in Form 3 textbook

\begin{tabular}{|c|c|l|}
\hline Modals taught & $\begin{array}{c}\text { Semantic } \\
\text { functions }\end{array}$ & \multicolumn{1}{|c|}{ Exercises } \\
\hline May & possibility & Task 1: Slot-fillers (choice of answers provided) \\
\hline Might & possibility & Task 2: Open-ended \\
\hline Can & ability & Task 3: Slot-fillers (choice of answers provided) \\
\hline Must & necessity & Task 4: Write sentences \\
\hline Will & Future plans & Task 5: Slot-fillers (choice of answers provided) \\
\hline
\end{tabular}

Table 4. Summary of modals taught, their semantic functions and practice tasks in Form 4 textbook

\begin{tabular}{|c|c|l|}
\hline Modals taught & $\begin{array}{c}\text { Semantic } \\
\text { functions }\end{array}$ & \multicolumn{1}{|c|}{ Exercises } \\
\hline Should & advice & $\begin{array}{l}\text { Task 1: Open-ended } \\
\text { Task 2: Slot-fillers (choice of answers provided) }\end{array}$ \\
\hline
\end{tabular}

Table 5. Summary of modals taught, their semantic functions and practice tasks in Form 5 textbook

\begin{tabular}{|c|c|c|}
\hline Modals taught & $\begin{array}{l}\text { Semantic } \\
\text { functions }\end{array}$ & \multicolumn{2}{|c|}{ Exercises } \\
\hline May & possibility & Task 1: Open-ended \\
\hline Might & possibility & \\
\hline Will & Future plans & $\begin{array}{l}\text { Task 2: Slot-fillers (choice of answers provided) } \\
\text { Task 3: Slot-fillers (choice of answers not } \\
\text { provided) }\end{array}$ \\
\hline
\end{tabular}




\begin{tabular}{|c|c|c|c|c|}
\hline $\begin{array}{l}\text { I } \\
\text { You } \\
\text { He } \\
\text { Mailin }\end{array}$ & & will & $\begin{array}{l}\text { call the students for a meeting } \\
\text { discuss the problem with the teacher } \\
\text { collect donations for the campaign } \\
\text { ask the librarian for some books }\end{array}$ & $\begin{array}{l}\text { soon. } \\
\text { tomorrow. } \\
\text { next week. }\end{array}$ \\
\hline $\begin{array}{l}\text { Sufian } \\
\text { She }\end{array}$ & is & \multirow{2}{*}{ going to } & \multirow{2}{*}{$\begin{array}{l}\text { the computer room } \\
\text { Lee Mei's house to discuss the project } \\
\text { ask the principal for advice } \\
\text { Kuala Lumpur }\end{array}$} & \multirow{2}{*}{$\begin{array}{l}\text { later. } \\
\text { today. } \\
\text { next month. }\end{array}$} \\
\hline $\begin{array}{l}\text { They } \\
\text { We }\end{array}$ & are & & & \\
\hline
\end{tabular}

Figure 1. A sample shot ofwill and going toin a given practice task in Form 1 textbook

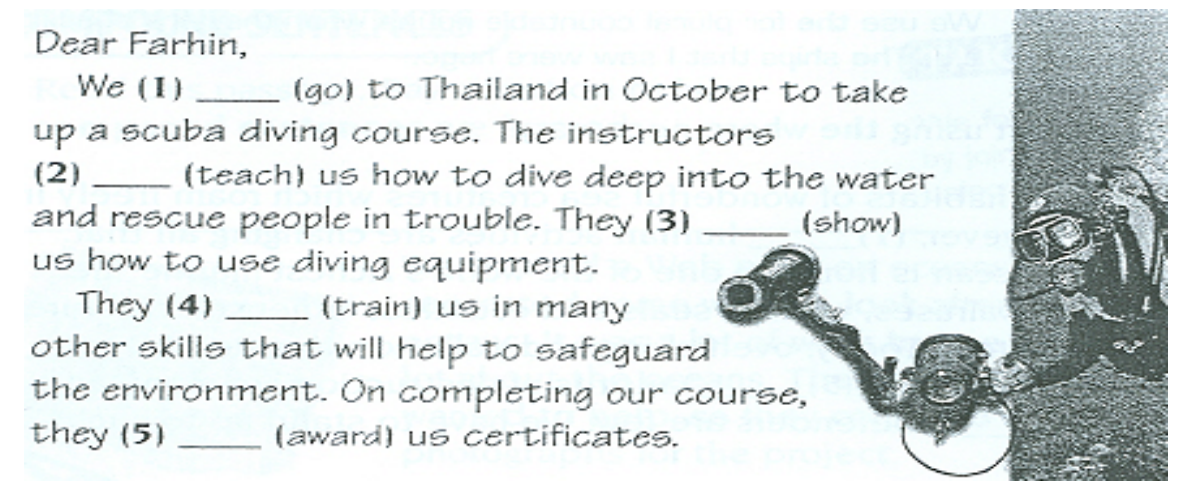

Figure 2. A sample shot of will in a given practice task in Form 3 textbook

\section{Change the verbs in the sentences below to indicate the future using 'will'.}

1 It ... (be) the end-of-year holidays next week.

2 The teachers are certain that Erik ... (win) the elocution contest.

3 "Someone needs to arrange for transport." - "Okay, I ... (do) it."

4 The various student bodies ... (combine) to celebrate Malaysia's National Day.

Figure 3. A sample shot of will in a given practice task in Form 5 textbook 